\title{
Factors influencing the incidence of gonorrhoea and non-gonococcal urethritis in men in an industrial city
}

\author{
L. Z. OLLER, M.D., AND T. WOOD, S.R.N. \\ St. Luke's Hospital, Bradford, Yorks.
}

The incidence of gonorrhoea and of non-gonococcal urethritis (NGU) has increased in Great Britain, and statistics from England and Wales show that in the last 4 years the incidence of NGU exceeded that of gonorrhoea. Epidemiological differences between these two diseases were studied in London by Boyd, Csonka, and Oates (1958), who compared 200 cases of gonorrhoea with an equal number of cases of NGU, and in Newcastle by Macfarlane and Johns (1958), who compared 100 cases of each disease. In both studies the absence of promiscuity among the patients with NGU and their sexual contacts appeared to be the principal distinguishing feature between the two diseases. Statistics from four clinics in Yorkshire showed that gonorrhoea was twice as common in coloured immigrants as in white men, whereas NGU was twice as common in white men (Morrison, 1963). This has been the experience of all venereologists working in towns which have large settlements of coloured immigrants.

This paper reports the results of a retrospective study of 5,752 cases of gonorrhoea and 3,486 cases of NGU treated at the Venereal Disease Clinic in Bradford, an industrial city in Yorkshire with an estimated population of 298,000 . Immigration, sexual behaviour, age, and occupation with special reference to students were reviewed as possible factors which might have had a bearing on the prevalence of one or other of these diseases.

\section{Immigration}

It is estimated (Fig. 1) that from 1955 to the end of June, 1962, a total of 472,400 coloured immigrants came to Great Britain. Approximately half of them were from the West Indies, 100,000 from India and Pakistan, and the rest from African Commonwealth countries. Over 231,000 arrived in the last 18-month period before July 1, 1962, when the parliamentary Immigration Act came into force. This Act limited the number of new immigrants but placed no restriction on the families of those already settled: $\mathrm{Up}$ to the end of 1967, the number of immigrants has since

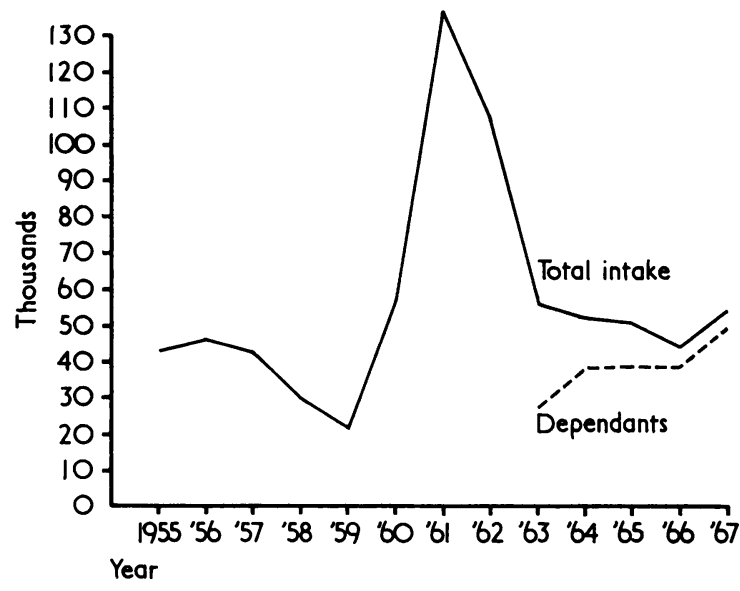

F I G. 1 Estimated annual intake of coloured Commonwealth immigrants into the United Kingdom, 1955-57

increased by a further 271,669-mostly wives and children. Of over 99,000 immigrants who came in 1966-1967, more than 89,000 were wives and children.

An annual assessment of the number of immigrants coming to Bradford has not been made, but the immigrant population settled in the city was estimated in 1961, 1963, 1966, and 1967 (Table I). With immigrants forming 5 to 7 per cent. of the local popu-

TABLE I Estimated numbers of the coloured immigrant population in Bradford, 1961-1967

\begin{tabular}{|c|c|c|c|c|c|}
\hline Race &. & $\begin{array}{l}\text { West } \\
\text { Indian }\end{array}$ & Indian & Pakistani & Total \\
\hline \multirow[t]{4}{*}{ Year } & $\begin{array}{l}1961 \\
\text { (Census) }\end{array}$ & $\begin{array}{l}984 \\
3: 2 \text { men }\end{array}$ & $\begin{array}{l}\text { 1,512 } \\
3: 1 \text { men }\end{array}$ & $\begin{array}{l}3,457 \\
81 \text { women }\end{array}$ & 5,953 \\
\hline & $\begin{array}{l}1963 \\
\text { (Estimate) }\end{array}$ & 1,500 & 3,000 & 7,000 & $\begin{array}{r}11,500 \\
\end{array}$ \\
\hline & $\begin{array}{l}1966 \\
\text { (Sample }\end{array}$ & 1,690 & 3,600 & 7,030 & 12,320 \\
\hline & $\begin{array}{l}1967 \\
\text { (Estimate) }\end{array}$ & 2,000 & 4,000 & 15,000 & 21,000 \\
\hline
\end{tabular}



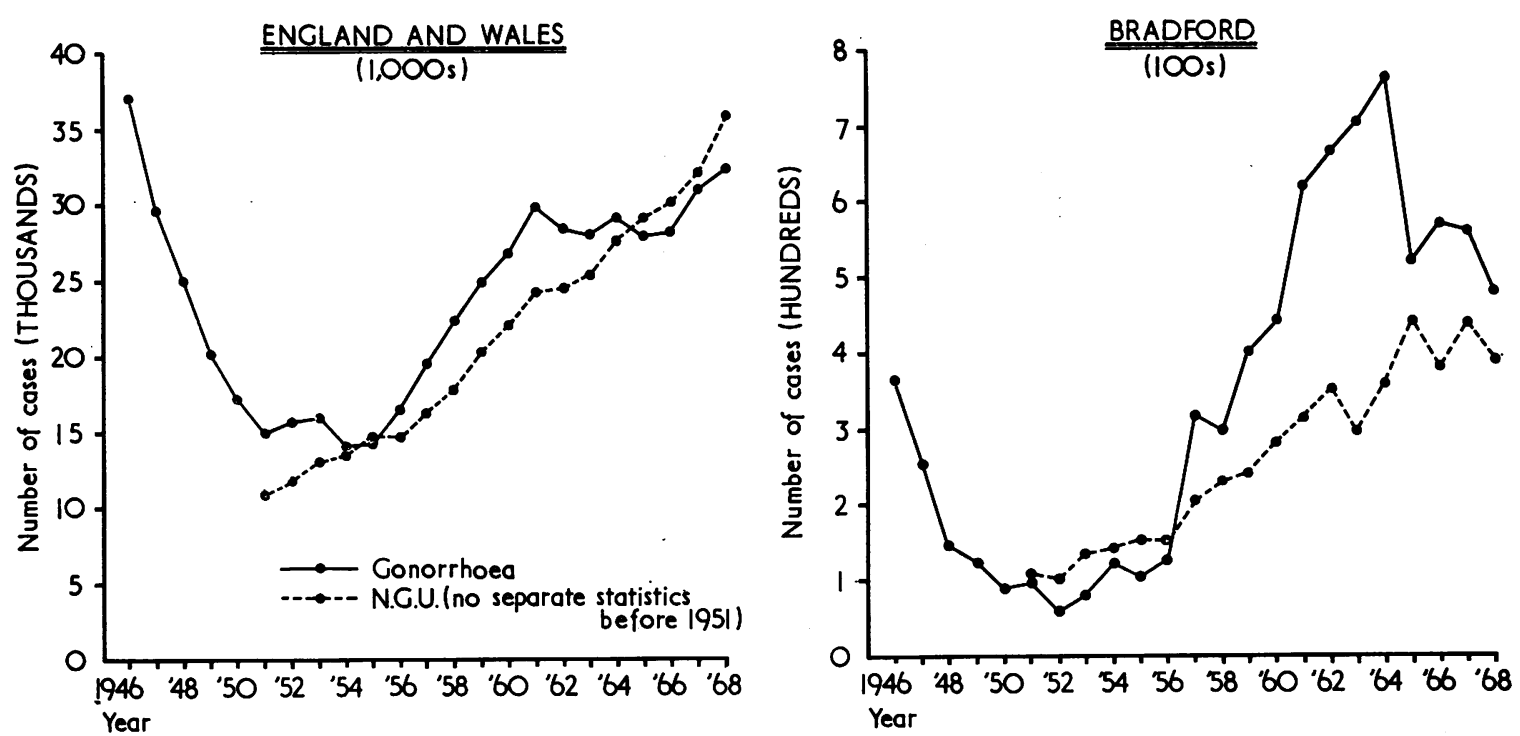

FIG. 2 Incidence of NGU and gonorrhoea in men, 1946-68. Bradford compared with England and Wales

lation, Bradford is one of their largest settlements in the United Kingdom and has the largest community of Asians (mostly Pakistanis) in the country.

The effect of this recent massive immigration on the increase in the incidence of gonorrhoea in Great Britain has been described by Willcox (1966).

A comparison of the incidence of gonorrhoea and NGU in England and Wales with that in Bradford in

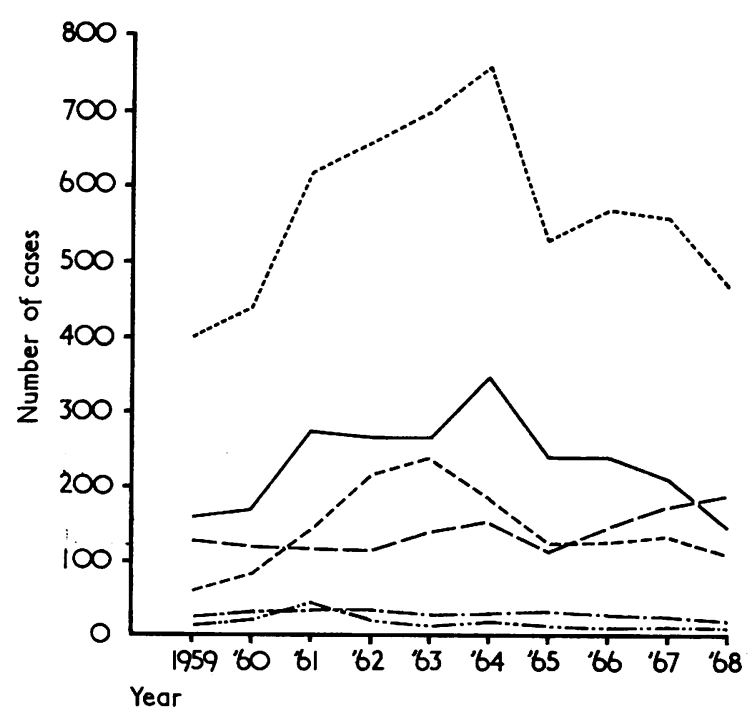

FIG. 3 Incidence of gonorrhoea in men in Bradford, 1959-68, by race the post-war years (Fig. 2), shows that the number of cases of gonorrhoea on the national scale has never reached the peak of 1946, whereas in Bradford already: in 1959 it exceeded it by 12 per cent. and by 1964 was more than double. In contrast, the curves for NGU are essentially similar, though that for Bradford shows a few annual fluctuations. The upward trend in the incidence of gonorrhoea in Bradford since 1955
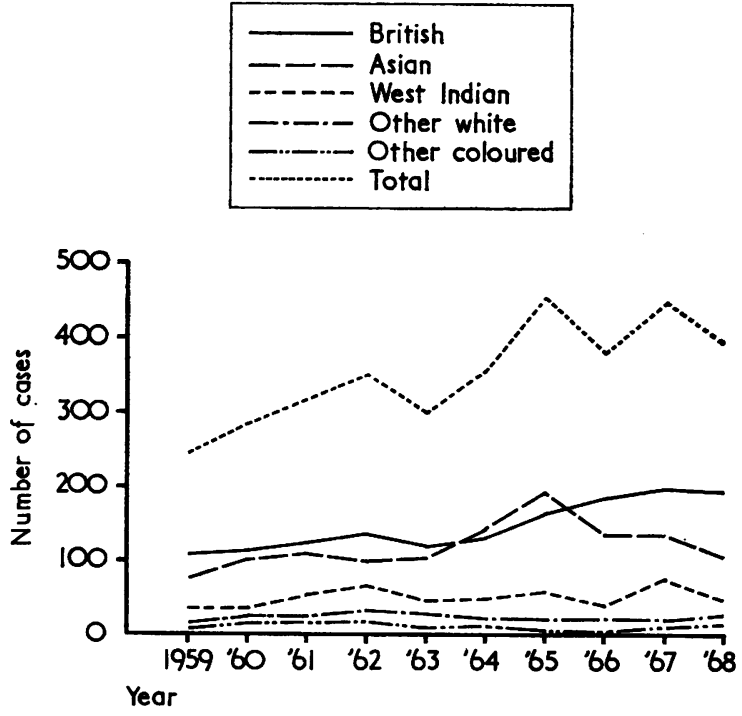

FIG. 4 Incidence of NGU in men in Bradford, 1959-68, by race 


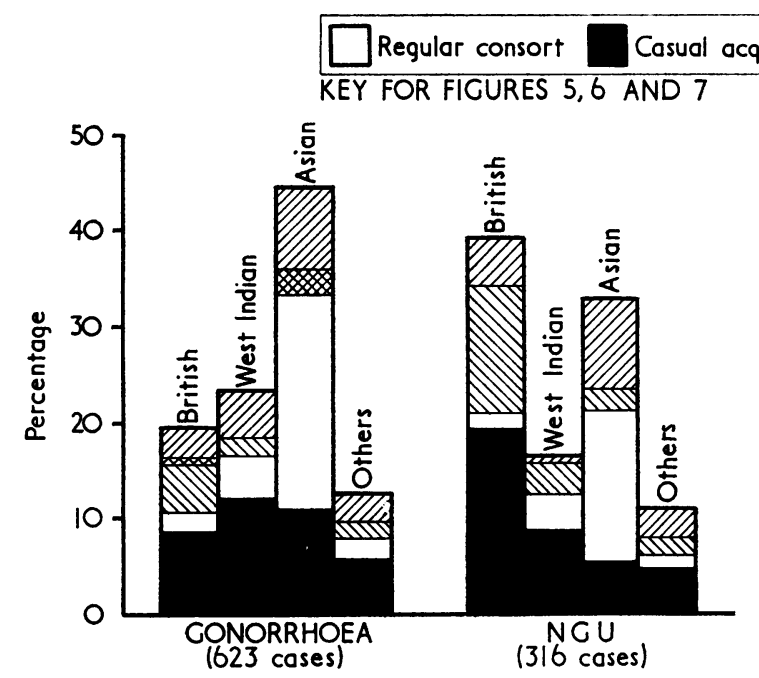

FIG. 5 Sources of infection with gonorrhoea and NGU, 1961, by race

was twice interrupted, in 1958 and 1965, when the routine dose of penicillin for the treatment of gonorrhoea was increased - from 300,000 to 600,000 units in January, 1958, and again to 1.2 mega units in January, 1965. The effect of this increased dose was relatively small in 1958 (a decrease of 8.7 per cent. against a background of a rapidly rising number of immigrant men, but was substantial in 1965 (a drop of 31 per cent.) against a background of a decline in incoming men and the arrival of the wives.

GONORRHOEA (Fig. 3, see p. 97)

Unlike the rest of the country, where the West Indians have made the greatest impact on the incidence of gonorrhoea, in Bradford the Asians accounted for most of the cases. In the years 1959 to 1966 they were responsible each year for an average 44 per cent. of cases of gonorrhoea. In 1966 the number of cases among the British men began to rise, and in 1968 for the first time in the decade under review British males accounted for 42 per cent. of the cases, more than any other racial group. West Indians on the average contributed between 23 and 24 per cent. to the total incidence of gonorrhoea, excluding the years 1962 and 1963 when it is believed that many West Indian men settled temporarily in Bradford; in each of these two years they accounted for 32 per cent. of the infections. The share of other immigrants, white or coloured, averaged 11 per cent. in the first 3 years and 6.5 per cent. in the 7 later years.

NGU (Fig. 4, see p. 97)

This was more common in British males than in any

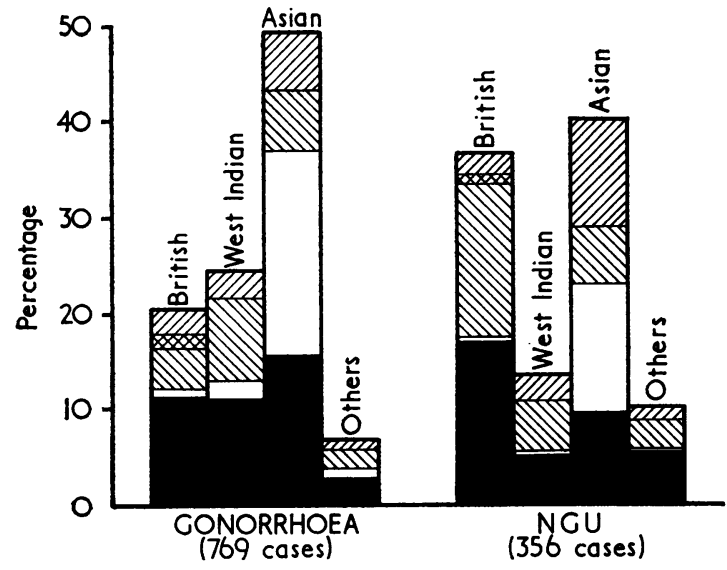

FIG. 6 Sources of infection with gonorrhoea and NGU, 1964, by race

of the immigrant men, and in 5 of the 10 years the number of cases of NGU surpassed the number of cases of gonorrhoea. In all the immigrant groups gonorrhoea was prevalent, the ratio of gonorrhoea to NGU averaging approximately 3:1 amongst the West Indians, 2:1 amongst the Asians and other coloured immigrants, and $3: 2$ in the white immigrants. Only in two years, 1964 and 1965, was the number of cases of NGU higher amongst the Asians than amongst the British males. However, in our experience, Asians, more than any other men, are inclined to suffer from minimal urethral discharge which for statistical reasons, not on clinical grounds, is labelled NGU.

In the 6-year period 1963 to 1968, there were 28 cases of NGU associated with arthritis or synovitis; the percentage $(1 \cdot 2)$ is slightly higher than the cumulative percentage from all other clinics in England and Wales which was $1 \cdot 1$ in the same period.

\section{Sexual behaviour}

To deal with this aspect of the study three sample years were chosen and all case histories of patients with the diagnosis gonorrhoea or NGU within these years were perused and the alleged sources of infection noted. The selected years included 1961 (Fig. 5) the year in which the incidence of both diseases was rapidly rising, 1964 (Fig. 6) the year in which the incidence of gonorrhoea reached its peak and that of NGU was higher amongst the Asians than amongst the British, and 1967 (Fig. 7, opposite) in which the incidence of gonorrhoea was increasing among the British and decreasing among the Asians and that of NGU was very high in comparison with the previous 


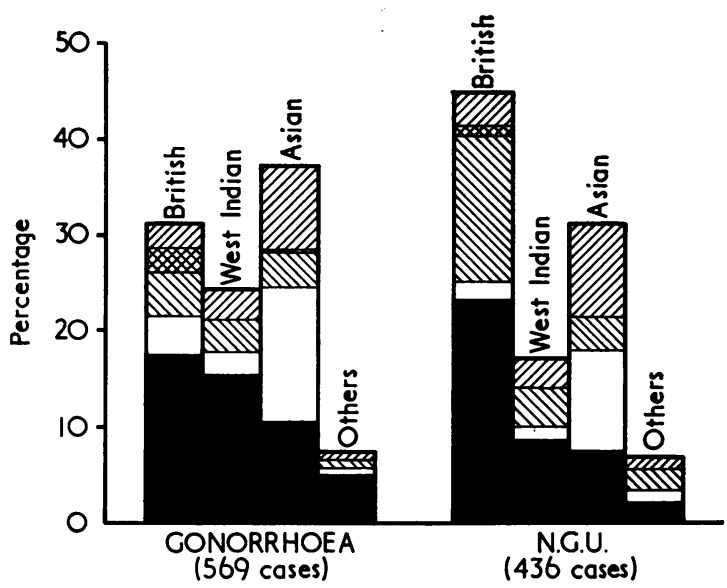

FIG. 7 Sources of infection with gonorrhoea and NGU, 1967, by race

years. The aggregate of the 3 years should reflect the trends in sexual behaviour for the whole decade under review (Fig. 8, Table II, below). In the aggregate, cases in which the source of infection was not established are omitted.

Sexual contacts hav been divided into four categories, as follows:

(1) Regular consort (wife, concubine, fiancée or girlfriend);

(2) Prostitute (where money was paid for service rendered);

(3) Casual acquaintance (any female who did not fall into the two previous categories);

(4) Homosexual (without further qualification).

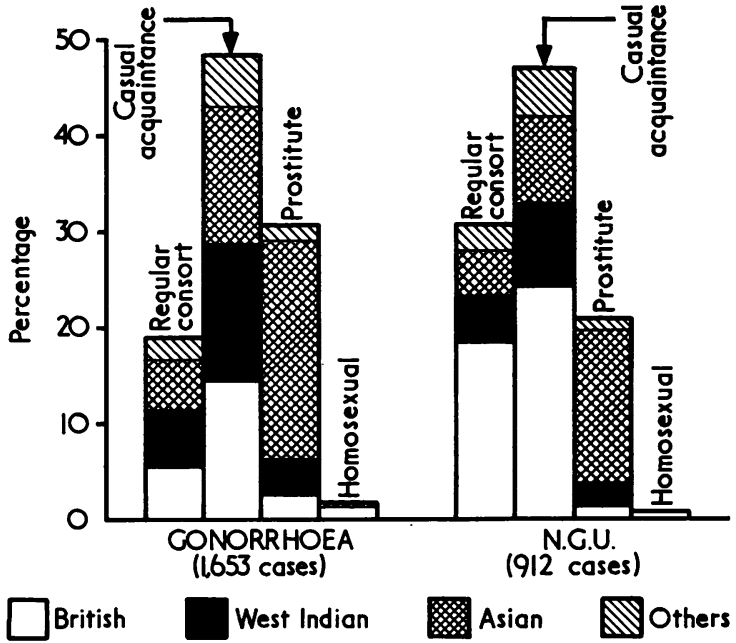

F I G . 8 Total sources of infection with gonorrhoea and NGU, 1961, 1964, 1967, by race

The following points should be noted in the consideration of these data:

(i) The sexual habits of the main immigrant groups are different. Asians are accustomed to seek relief of their sexual desire through prostitutes and to pay for it. West Indians believe in free love in every meaning of the word free, including payment. Therefore in many instances a woman who is defined as a prostitute in the case of an Asian, may be defined as a casual acquaintance in the case of a West Indian, and a regular consort in the case of another immigrant who lives on her immoral earnings.

(ii) The type of white girl who is attracted by a coloured immigrant rarely consorts with a white man.

TABLE II Sources of infection (cumulative total 1961, 1964, 1967)*

\begin{tabular}{|c|c|c|c|c|c|c|c|c|c|c|c|}
\hline \multirow{3}{*}{ Infection } & \multirow{3}{*}{ Source } & \multicolumn{10}{|l|}{ Race } \\
\hline & & \multicolumn{2}{|c|}{ British } & \multicolumn{2}{|c|}{$\begin{array}{l}\text { West } \\
\text { Indian }\end{array}$} & \multicolumn{2}{|c|}{ Asian } & \multicolumn{2}{|c|}{ Other } & \multicolumn{2}{|l|}{ Total } \\
\hline & & No. & $\begin{array}{l}\text { Per } \\
\text { cent. }\end{array}$ & No. & $\begin{array}{l}\text { Per } \\
\text { cent. }\end{array}$ & No. & $\begin{array}{l}\text { Per } \\
\text { cent. }\end{array}$ & No. & $\begin{array}{l}\text { Per } \\
\text { cent. }\end{array}$ & No. & $\begin{array}{l}\text { Per } \\
\text { cent. }\end{array}$ \\
\hline \multirow[t]{2}{*}{ Gonorrhoea } & $\begin{array}{l}\text { Regular consort } \\
\text { Casual acquaintance } \\
\text { Prostitute } \\
\text { Homosexual }\end{array}$ & $\begin{array}{r}92 \\
238 \\
45 \\
28\end{array}$ & $\begin{array}{r}5 \cdot 5 \\
14 \cdot 4 \\
2 \cdot 8 \\
1 \cdot 8\end{array}$ & $\begin{array}{r}97 \\
246 \\
56 \\
\end{array}$ & $\begin{array}{r}6.0 \\
14.5 \\
3.5 \\
-\end{array}$ & $\begin{array}{r}82 \\
249 \\
376 \\
1\end{array}$ & $\begin{array}{r}5 \cdot 1 \\
14 \cdot 6 \\
22 \cdot 8 \\
0 \cdot 1\end{array}$ & $\begin{array}{l}33 \\
84 \\
26 \\
-\end{array}$ & $\begin{array}{l}2 \cdot 1 \\
5 \cdot 2 \\
1 \cdot 6 \\
-\end{array}$ & $\begin{array}{r}304 \\
817 \\
503 \\
29\end{array}$ & $\begin{array}{r}18 \cdot 7 \\
48 \cdot 7 \\
30 \cdot 7 \\
1 \cdot 9\end{array}$ \\
\hline & Total & 403 & $24 \cdot 5$ & 399 & $24 \cdot 0$ & 708 & $42 \cdot 6$ & 143 & $8 \cdot 9$ & 1,653 & $100 \cdot 0$ \\
\hline \multirow[t]{2}{*}{ NGU } & $\begin{array}{l}\text { Regular consort } \\
\text { Casual acquaintance } \\
\text { Prostitute } \\
\text { Homosexual }\end{array}$ & $\begin{array}{r}167 \\
221 \\
15 \\
8\end{array}$ & $\begin{array}{r}18 \cdot 3 \\
24 \cdot 3 \\
1 \cdot 6 \\
0 \cdot 9\end{array}$ & $\begin{array}{l}46 \\
82 \\
21 \\
-\end{array}$ & $\begin{array}{l}5 \cdot 0 \\
9 \cdot 0 \\
2 \cdot 4 \\
-\end{array}$ & $\begin{array}{r}43 \\
84 \\
144 \\
\end{array}$ & $\begin{array}{r}4 \cdot 7 \\
9 \cdot 2 \\
15 \cdot 8 \\
-\end{array}$ & $\begin{array}{l}25 \\
44 \\
12 \\
-\end{array}$ & $\begin{array}{l}2 \cdot 7 \\
4 \cdot 8 \\
1 \cdot 3 \\
-\end{array}$ & $\begin{array}{r}281 \\
431 \\
192 \\
8\end{array}$ & $\begin{array}{r}30 \cdot 7 \\
47 \cdot 3 \\
21 \cdot 1 \\
0 \cdot 9\end{array}$ \\
\hline & Total & 411 & $45 \cdot 1$ & 149 & $16 \cdot 4$ & 271 & 29.7 & 81 & $8 \cdot 8$ & 912 & $100 \cdot 0$ \\
\hline
\end{tabular}

^Cases in which source was not established are excluded 
A woman described as a casual acquaintance by a coloured immigrant is as a rule more promiscuous than the casual acquaintance of a British male.

(iii) The British male is sometimes infected with gonorrhoea by his wife; but, apart from one West Indian wife, we have never seen a wife of an immigrant who has infected her husband with gonorrhoea, though the reverse is often true. On the other hand, both British and immigrant males name their wives as the source of infection with NGU.

Analysis of the figures in Table II shows that the Asian men were most frequently infected with both gonorrhoea (53.1 per cent.) and NGU (53.0 per cent.) by prostitutes, whereas men in all the other racial groups mostly acquired the two diseases from casual acquaintances. Gonorrhoea came from casual acquaintances in 59.3 per cent. of the British, 61.8 per cent. of the West Indians, and 58:8 per cent. of the other immigrants, and NGU in $53.8,55.0$, and 54.4 per cent. respectively.

In all groups a significantly higher percentage of NGU than that of gonorrhoea was acquired from a regular consort; this was part icularly noticeable in the British group ( 40.8 per cent. of NGU and 22.8 per cent: of gonorrhoea). In the other groups the proportions of infections transmitted by regular consorts were:

Asians: NGU 15.9, gonorrhoea 11.5 per cent.

West Indians: 30.9 and 27.5 per cent.

Other immigrants: 30.9 and 23.1 per cent.

Apart from one Asian all the homosexual patients were British. The 28 cases of gonorrhoea acquired from this source include 22 cases of urethral and six cases of rectal infection.
Age

The age of the patients was considered over a period of 8 years and in the three sample years a detailed analysis was made to arrive at the average age (Table III). This was slightly (but not significantly) higher in the NGU than in the gonorrhoea group. It is noteworthy that in the youngest age group of up to 20 years, in six out of the eight years, the percentage of cases of NGU was higher than the percentage of cases of gonorrhoea, and that in three years the number of cases of NGU was also greater. These young people in all racial groups are rarely the clients of prostitutes.

\section{Occupation}

Bradford is the centre of the wool industry and 27 per cent. of the working population is employed in it.

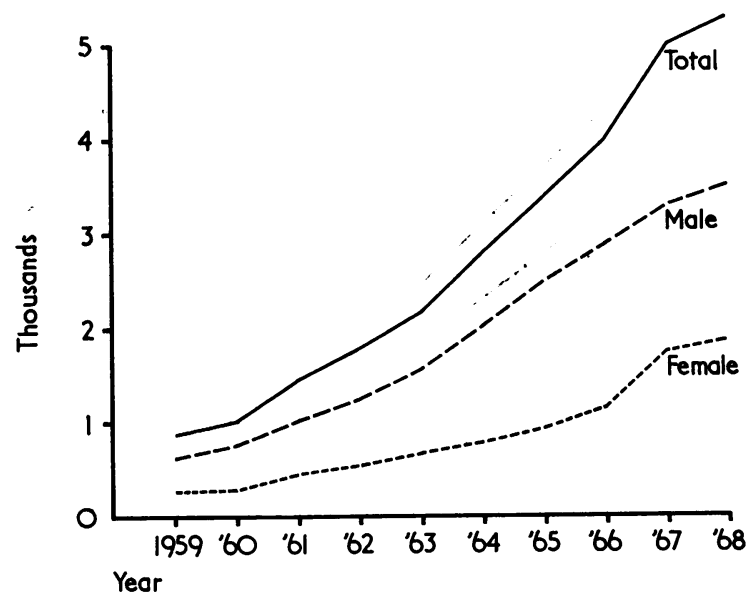

FIG. 9 Bradford whole-time student populationn, 1959-68, by sex

TABLE III Age groups of patients (1961-68) and average ages in 1961, 1964, and 1967

\begin{tabular}{|c|c|c|c|c|c|c|c|c|}
\hline \multirow{3}{*}{ Infection } & \multirow{3}{*}{ Year } & \multicolumn{6}{|c|}{ Age group (yrs) } & \multirow{3}{*}{$\begin{array}{l}\text { Average } \\
\text { age }\end{array}$} \\
\hline & & \multicolumn{2}{|c|}{$<20$} & \multirow[b]{2}{*}{$21-25$} & \multirow[b]{2}{*}{$26-30$} & \multirow[b]{2}{*}{$31-39$} & \multirow[b]{2}{*}{$40>$} & \\
\hline & & No. & Per cent. & & & & & \\
\hline NGU & $\begin{array}{l}1961 \\
1962 \\
1963 \\
1964 \\
1965 \\
1966 \\
1967 \\
1968\end{array}$ & $\begin{array}{l}20 \\
14 \\
17 \\
10 \\
24 \\
25 \\
46 \\
27\end{array}$ & $\begin{array}{r}6 \cdot 5 \\
4 \cdot 0 \\
5 \cdot 7 \\
2 \cdot 8 \\
5 \cdot 5 \\
6 \cdot 6 \\
10 \cdot 5 \\
7 \cdot 0\end{array}$ & $\begin{array}{l}60 \\
94 \\
74 \\
91 \\
74 \\
67 \\
60 \\
63\end{array}$ & $\begin{array}{r}76 \\
79 \\
80 \\
101 \\
128 \\
118 \\
126 \\
100\end{array}$ & $\begin{array}{r}118 \\
126 \\
89 \\
103 \\
145 \\
113 \\
136 \\
124 \\
.\end{array}$ & $\begin{array}{l}42 \\
37 \\
37 \\
51 \\
69 \\
56 \\
68 \\
73\end{array}$ & $\begin{array}{l}30.8 \\
30 \cdot 9 \\
31 \cdot 0\end{array}$ \\
\hline Gonorrhoea & $\begin{array}{l}1961 \\
1962 \\
1963 \\
1964 \\
1965 \\
1966 \\
1967 \\
1968\end{array}$ & $\begin{array}{l}15 \\
26 \\
29 \\
22 \\
20 \\
30 \\
37 \\
37\end{array}$ & $\begin{array}{l}2 \cdot 4 \\
4 \cdot 0 \\
4 \cdot 1 \\
2 \cdot 9 \\
3 \cdot 8 \\
5 \cdot 4 \\
6 \cdot 5 \\
7 \cdot 7\end{array}$ & $\begin{array}{r}140 \\
139 \\
212 \\
219 \\
146 \\
122 \\
92 \\
106\end{array}$ & $\begin{array}{l}196 \\
227 \\
233 \\
272 \\
174 \\
200 \\
197 \\
142\end{array}$ & $\begin{array}{l}223 \\
182 \\
171 \\
190 \\
130 \\
163 \\
165 \\
132\end{array}$ & $\begin{array}{l}49 \\
69 \\
61 \\
66 \\
60 \\
53 \\
78 \\
60\end{array}$ & $\begin{array}{l}29 \cdot 2 \\
30 \cdot 8\end{array}$ \\
\hline
\end{tabular}


Therefore it is not surprising that the incidence of both gonorrhoea ( 31 to 40 per cent.) in various years and NGU (30 to 31 per cent.) was highest amongst the textile workers.

\section{Students}

In the decade under review the student population in the university and main colleges in Bradford increased nearly six-fold from 882 (622 male) students in 1959 to 5,279 (3,454 male) in 1968 (Fig. 9, opposite).

In this period 242 male students attended the V.D. Clinic (Fig. 10). Although the number attending the Clinic increased 4-fold, the incidence of gonorrhoea remained on a low level while that of NGU increased. Over the whole period there were fifty cases of gonorrhoea and 79 cases of NGU (Fig. 11). The majority of patients with gonorrhoea (29) came from African countries, six from Asia, and four from European

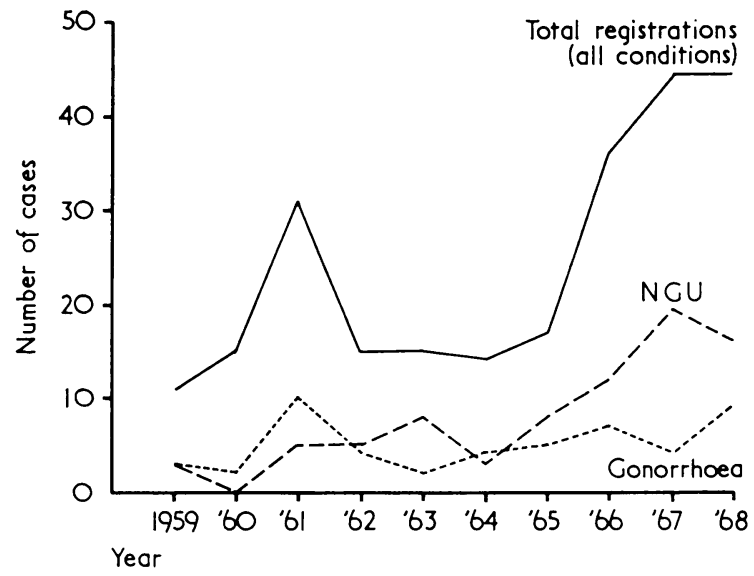

FIG. 10 Male students registered at Bradford VD clinic, 1959-68

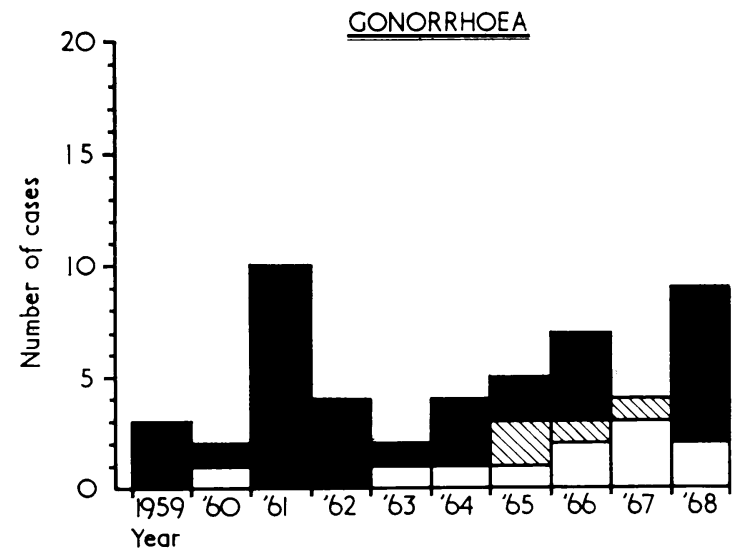

countries, and eleven were British. In contrast, the majority of patients with NGU (44) were British, ten were other Europeans, 21 were from Africa, and four from Asia. There were no West Indians amongst the student patients.

Frequently the consort of a student is a female student, but as there are few female students from African countries, the African students tend to associate with local promiscuous females. Table IV shows the source of infection of students. Casual acquaintances played the most important part in the transmission of both infections, and next came regular consorts. The clients of prostitutes were all African students. The three homosexuals were all British.

TABLE IV Sources of infection in male students, 19591968

\begin{tabular}{|c|c|c|c|}
\hline \multicolumn{2}{|l|}{ Infection } & \multirow{2}{*}{$\begin{array}{l}\text { Gonorrhoea } \\
14 \\
24 \\
6 \\
1 \\
5\end{array}$} & \multirow{2}{*}{$\begin{array}{l}N G U \\
27 \\
41 \\
5 \\
2 \\
4\end{array}$} \\
\hline Source & $\begin{array}{l}\text { Regular Consort } \\
\text { Casual Acquaintance } \\
\text { Prostitute } \\
\text { Homosexual } \\
\text { Not established }\end{array}$ & & \\
\hline & Total & 50 & 79 \\
\hline
\end{tabular}

\section{Summary and Conclusions}

(1) Records of 5,752 cases of gonorrhoea and of 3,486 cases of NGU treated at the V.D. Clinic in Bradford in the 10-year period 1959 to 1968 were reviewed and data of factors which might have influenced the incidence of the two diseases were noted and analysed.

(2) Massive immigration of single men in the first half of that decade was the main factor contributing to the increase in the incidence of gonorrhoea. In the first 7 years immigrant men accounted for 80 per cent.

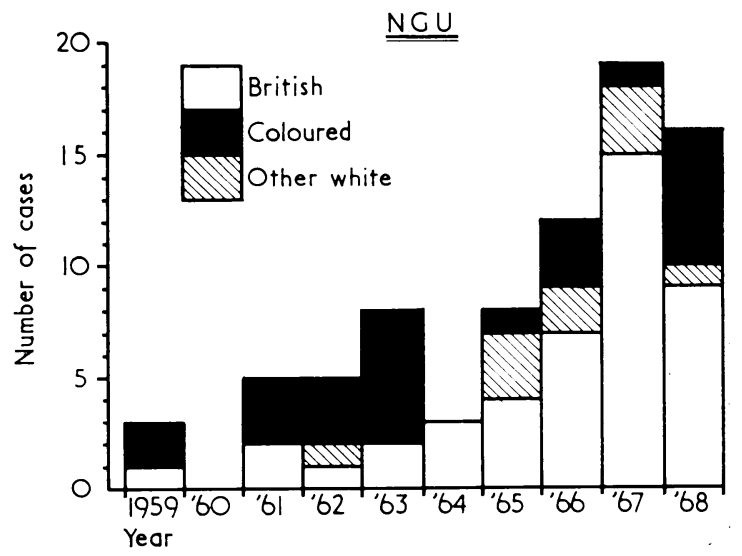

F I G. 11 Incidence of gonorrhoca and NGU in male students in Bradford, 1959-68, by race 
of the cases of gonorrhoea. In the three following years the arrival of the wives of many immigrants resulted in a decline of gonorrhoea amongst the immigrant men and there was at the same time a rise amongst the British men.

In the same period NGU was prevalent among the British, who accounted for 1,465 cases of NGU and 1,433 cases of gonorrhoea.

In all the immigrant groups gonorrhoea was predominant, its proportion to NGU being approximately 3:1 among the West Indians, 2:1 among the Asians and Africans, and 3:2 among the Europeans. (3) Although both infections were mainly acquired from casual acquaintances (from prostitutes by the Asians), in all racial groups a higher proportion of men with NGU than of those with gonorrhoea were infected by regular consorts.

(4) There was not much difference in average age between the two groups, but the percentage of youngsters up to 20 years was significantly higher in the NGU group.

(5) In these 10 years students accounted for fifty cases of gonorrhoea and 79 cases of NGU. The majority of the former occurred in African students (29) and the majority of the latter in British students (43).

(6) As there are no structural differences in the urethral mucosa of any male, whatever his race, there is no valid reason to suppose that any particular race is more susceptible to one or the other of the two infections. Therefore the difference in incidence of the two infections between the British and immigrant males lies not in the colour of their skin but in their sexual habits. A new immigrant in a strange country finds it easier to mix with promiscuous women and prostitutes, who are usually the main reservoir of gonorrhoea, but any explanation why NGU is frequently transmitted by a regular consort must be speculative until the causative agent is discovered.

We wish to thank Mrs. M. Allan and Mrs. N. Farrar, clerks to the Department, and Mr. C. Fordon, S.R.N., and his staff for their help in compiling the data for this study.

\section{References}

BOYD, J. T., CsONKA, G. W., and OATES, J. K. (1958). Brit. f. vener. Dis., 34, 40.

MACFARLANE, W. V., and JoHNs, H. M. (1958). Ibid., 34, 101.

MORRISON, A. I. (1963). Ibid., 39, 118.

WILlcox, R. R. (1966). Ibid., 42, 225.
Facteurs influençant l'incidence des urétrites gonococciques et non gonococciques, chez l'homme, dans une cité industrielle

\section{SOMMAIRE ET CONCLUSIONS}

(1) Les fiches de 5.752 cas de gonococcie et de 3.486 cas d'U.N.G. traités au Dispensaire vénéréologique de Bradford dans la période de 10 ans, 1959-68, furent passées en revue et les informations sur les facteurs ayant pu influer sur l'incidence des deux maladies furent notés et analysés.

(2) Au cours de la première moitié de cette décennie, l'immigration massive d'hommes célibataires a constitué le facteur majeur contribuant à augmenter l'incidence de la gonococcie. Pour les sept premières années, les immigrants représentent 80 pour cent des cas de gonococcie. Au cours des trois années suivantes, l'arrivée des femmes de beaucoup d'immigrants entraîna une diminution de la gonococcie parmi ceux-ci, en même temps qu'augmentait le nombre des cas parmi les Britanniques. Pendant la même période, les U.N.G. furent prévalentes chez les Britanniques: 1.465 cas d'U.N.G. contre 1.433 cas de gonococcie. La gonococcie fut prédominante dans tous les groupes d'immigrants; le taux, par rapport aux U.N.G., étant approximativement de $3 / 1 \mathrm{chez}$ les Antillais, $2 / 1$ chez les Asiatiques et les Africains, et de $3 / 2$ chez les Européens continentaux.

(3) Quoique les deux infections fussent généralement dues à des rencontres occasionnelles (avec des prostituées pour les Asiatiques), dans tous les groupes raciaux une plus grande proportion d'hommes atteints d'U.N.G., par rapport à ceux atteints de gonococcie, fut infectée par des partenaires régulières.

(4) Il n'y eut pas beaucoup de différence dans les moyennes d'âge entre les deux groupes, mais le pourcentage de jeunes jusqu'à 20 ans fut significativement plus élevé dans le groupe des U.N.G.

(5) Pour ces dix années, on trouve, chez les étudiants, 50 cas de gonococcie et 79 cas d'U.N.G. Pour le premier groupe, il s'agit surtout d'étudiants africains (29); pour le deuxième, surtout d'étudiants britanniques (43).

(6) Comme il n'y a pas de différence de structure de la muqueuse urétrale masculine selon la race, il n'y a pas de raison valable de supposer qu'aucune race particulière est plus sensible à l'une ou à l'autre de ces deux infections. Ainsi, la différence observée dans l'incidence des deux infections entre les Britanniques et les immigrants ne tient pas à la couleur de leur peau, mais à leurs habitudes sexuelles. Un immigrant qui vient d'arriver dans un pays étranger trouve plus aisé de fréquenter des femmes faciles et des prostitutées, réservoir principal de la gonococcie, mais toute explication sur le fait que les U.N.G. sont fréquemment transmises par une partenair. régulière ne peut être qu'hypothèse, tant que l'agen، étiologique ne sera pas découvert. 